Birlesik Dünya Arastırma

BD-CENTER

Innovasyon ve Yayınellık Merkezi

\section{Global Journal of Arts Education}

Volume 11, Issue 1, (2021) 89-101

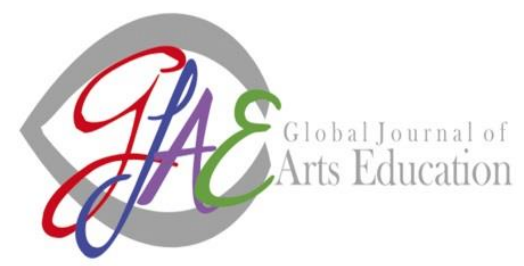

www.gjae.eu

\title{
Being a style icon in fashion world: Iris Apfel
}

Esra Varol ${ }^{\mathfrak{a}}$ 1, Niğde Ömer Halisdemir Üniversitesi Güzel Sanatlar Fakültesi Tekstil ve Moda Tasarımı Bölümü, Turkey

\section{Suggested Citation:}

Varola, E., (2021). Being a style icon in fashion world: Iris Apfel. Global Journal of Arts Education. 11(1), 89-101. https://doi.org/10.18844/gjae.v11i1.5727

Received from December 13, 2020; revised from January 18, 2021; accepted from March 05, 2021.

Selection and peer review under responsibility of Prof. Dr. Ayse Cakir Ilhan, Ankara University, Turkey.

${ }^{\circ} 2021$ Birlesik Dunya Yenilik Arastirma ve Yayincilik Merkezi. All rights reserved.

\begin{abstract}
The word fashion which expresses change and encompasses all areas of humanity is synonymous with clothing when taken in its narrow and common sense. People who can direct clothing fashion with their original clothing and appearances and are followed with great interest by public are called 'style icons'. As style icons, people from many different disciplines such as cinema, music, design, politics and sports have emerged with fashion and had an impact on clothing styles of different periods. One of the style icons of this era is Iris Apfel, who was born in Astoria in 1921, studied art and is known as an interior designer. The aim of this research is to examine the clothing style as well as all the visual elements (clothes, accessories, jewellery, hair, make-up etc.) that constitute the style of Iris Apfel as a style icon. The method of the research is qualitative in line with the research problem, purpose and the path followed in reaching the findings. Thus, a visual analysis of 10 photographs randomly selected from personal social media accounts or the internet was carried out. The findings obtained as a result of the analysis are presented in detail on each image.
\end{abstract}

Keywords: Fashion, clothing, style icon, Iris Apfel.

\footnotetext{
* ADDRESS FOR CORRESPONDENCE: Esra Varola, Niğde Ömer Halisdemir Üniversitesi Güzel Sanatlar Fakültesi Tekstil ve Moda Tasarımı Bölümü, Turkey

E-mail address: evarol@ohu.edu.tr
} 
Varola, E., (2021). Being a style icon in fashion world: Iris Apfel. Global Journal of Arts Education. 11(1), 89-101. https://doi.org/10.18844/gjae.v11i1.5727

\section{Introduction}

Fashion is 'temporary innovation that enters the life of society with the need for change or desire for decoration' (Ermert, 2019, p. 136). When fashion is considered in its narrow and widespread sense as consecutive changes of understanding seen in the society at various periods, it is seen as a synonym for dressing. Although change, which is the main feature of fashion, affects many areas, this effect is mostly seen in the field of clothing. The reason for this is that besides the indispensable need of human beings, clothing can be displayed more easily, more economically and in a shorter time than other fields (Hakko, 1983, p. 45; Girvy, 1999, p. 9). Fashion design, which differs from other design branches in that it is worn on the human body, is an art that reflects lifestyle through creative clothing. According to Lin (2007, p. 1) and Horn and Gurel (1981), this art creates a new fashion style: 'It is recognised as the ability to integrate trend information of fashion, market and consumer behaviour'.

It is not possible to consider every change presented to the society with the expectation that it can be fashionable, or that every product can be accepted as a representation of this change. In order for a change or a product to be accepted as a fashion, it must be adopted by the masses, in other words, it must be widespread: 'The process that passes in stages until the emergence, spread and replacement of a fashion is the fashion cycle' (Davis, 1997, p. 119). The fashion cycle can be compared to waves in the sea, i.e., when one wave disappears, another takes its place. Every fashion goes through periods of beginning, development and end, from being regarded as the pioneering innovation (avant-garde) of its time, to the time when it is deemed ordinary or obsolete (Figure 1). However, obsolescence in fashion is not the end. Some fashions are long-lived, others return unexpectedly by being rediscovered (Baudot, 2001, p. 8; Davis, 1997, p. 120; McKelvey \& Munslow, 2003, p. 28).

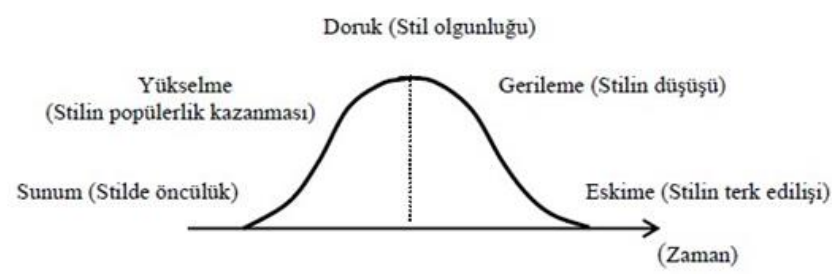

Figure 1. The fashion cycle

In today's increasingly accelerating fashion cycle, the role of the consumer in purchasing only the product offered to him has changed. According to Tok Dereci $(2017, p .83)$, when the subject is considered in terms of clothing design and clothing styles, consumers tend to make personal choices by combining the presented clothing pieces and form their styles with the shapes, colours and qualities they choose. This situation drives designers and garment design becomes an area where consumers can involve themselves in the design process.

Style or style concepts are defined in the TDK Contemporary Dictionary as 'special form of being or behaviour, jarn', 'style, telling, being, saying or way of doing' (URL-1). In line with these definitions, fashion or clothing style, 'silhouette, colour, texture, details and ornaments, which are formed by the use of design elements in various ways in line with the design principles and which have a common language with certain aspects, the forms, uses or it is possible to explain as views' (Varol, 2017, p. 43).

Clothes and dressing styles are elements of personal image as a non-verbal communication tool. Personal image is formed visually. People are appearance-oriented and the choices made regarding the appearance definitely constitute a judgment. Accordingly, clothing, as a part of the appearance, affects whether the judgments reached about people are positive or negative. According to researches, the judgments of people about each other in their first encounters are formed based on appearance 
Varola, E., (2021). Being a style icon in fashion world: Iris Apfel. Global Journal of Arts Education. 11(1), 89-101. https://doi.org/10.18844/gjae.v11i1.5727

(clothes, body language, physical characteristics etc.) with a rate of $90 \%$ within a few minutes. This situation, the first impression or 'the moment of truth', is effective in shaping personal and professional life. In order to provide a positive first impression and then to create the ideal personal image, the person should wear the right clothes in the appropriate style that provide confidence (Faux, 1999, pp. 14-15; Sampson, 1995, pp. 26-27).

\subsection{Clothing styles}

There are many different styles of clothing with design features. These clothing items can be worn together according to various common features such as models, colours, textures, decorations and messages that they associate, and certain known styles can be created, as well as very different and unique clothing styles can be created with the unique uses of people. With the transfer of Isler, Kocaman and Kilinc (2018, pp. 4-5), according to Yazici (2017, p. 104), the main clothing styles or styles are Bohemian, Preppy (College), Grunge, Gothic, Masculine, Feminine, Minimalist, Maximalist, Vintage, Retro, Avant-garde, Pop Art, Holographic, Ethnic, Monochrome, Elegant, Hippie, Sports, Baroque, Futurist, Military, Grunge, Sophisticated, Cowboy and Punk. In this diversity, some of the clothing styles and features of these styles are discussed below under related headings.

\subsubsection{Classic style}

According to Varol (2017, p. 44), Taggart and Walker (2003, pp. 61-62) and Cakir (2002, pp. 5253 ), in this style, the first clothes that come to mind in men's and women's clothing are suits. This style is mostly adopted by individuals working in traditional and conservative sectors such as banking, financial consultancy, politics, government services and public institutions. The messages conveyed by this style of clothing about the wearer are that they are serious, strict, reliable, knowledgeable and authoritative.

\subsubsection{Ethnic style}

In this style of clothing, the garments have cultural patterns, cuts, colours and different local textures. The clothes of this style are mostly made of natural weavings and are usually decorated with handcrafted local patterns (rug, geometric, floral etc.), embroideries and natural material, such as bone, seashell, wood and glass beads. These garments are complemented by jewellery made from culturally specific materials (wood, bone, glass beads etc.) and handcrafted. Some clothes for both men and women in this style of clothing are salwars, trousers, embroidered shirts, vests, jackets, cardigans and sweaters (Varol, 2017, p. 46).

\subsubsection{Punk style}

In this anti-fashion style, it is emphasised that there should be no class differences in society and the understanding that people who adopt the style will not belong to any class as long as these differences exist. Chains, safety pins, leather clothing, torn clothes or frayed socks, colourful and sewn hair are the most prominent highlights of the style (Olgac, 2014, p. 163).

\subsubsection{Retro style}

According to Kaba (2015, p. 36), with the transfer of Isler, Bor Kocaman and Kilinc (2018), flared trousers, floral-printed dresses, bell skirts, colourful socks and framed bone glasses are some of the basic clothing items used in this style.

\subsubsection{Bohemian style}

It is a style that influenced the 1970s, without thinking about tomorrow, and a free and carefree lifestyle. Flared trousers, embroidered tunics, layered skirts and long dresses are the main clothing items 
Varola, E., (2021). Being a style icon in fashion world: Iris Apfel. Global Journal of Arts Education. 11(1), 89-101. https://doi.org/10.18844/gjae.v11i1.5727

of the style. The use of mixed fabrics of different textures and types of cloth and the use of vibrant and warm colours on handcrafted accessories is in question (Olgac, 2014, p. 165).

\subsubsection{Masculine style}

The term masculine clothing mostly means that women adopted a masculine style of clothing. In this style of clothing, women use men's clothing and accessories such as ties and bow ties. The main parts of this style are trouser jacket suits, men's collar shirts, sweaters, vests, ties, bow ties, suspenders, heelless rubber or leather-soled sports, oxford or loafer shoes (Varol, 2017, p. 45).

\subsubsection{Romantic style}

With the transfer of Isler et al. (2018, p. 7), according to Yazici $(2017$, p. 117), this style, which emerged in Italy between 1815 and 1840, has been repeated from time to time in the fashion cycle and reached the present day. In this style, where fabrics such as silk, chiffon, taffeta, lace and tulle can be used, mostly in pastel shades, shirring, drape, flywheel or pleats are also used.

\subsubsection{Sporty style}

In this style, the importance of sports in a comfortable or healthy life is emphasised. Cargo or loosefitting denim trousers, hooded sweatshirts, t-shirts and tracksuits are the most distinctive pieces of clothing of this style. The complementary and indispensable parts of this style are sneakers.

\subsubsection{Minimalist style}

It is possible to use quality cutting, sewing and fabrics together with a simple, elegant appearance. Clothes that do not go out of fashion with fabrics in monochrome, dark or neutral tones are the main parts of this style. For example, black dress and white shirt are some of these clothes (Olgaç, 2014: 168).

\subsubsection{Maximalist style}

It is a style with exaggerated and large forms, and variegated or contrasting colours and different details are used. In addition to all kinds of sparkle, the most distinctive feature of the style is that there is a striking excess and exaggeration in the clothing, jewellery and accessories used (Olgac, 2014, p. 173).

\subsection{The concept of style icon in fashion}

A style icon is defined as 'a person who has his own style of clothing, but also has a completely unique stance' (Ermert, 2019, p. 178). These people can direct clothing fashion with their unique clothing and appearances and are followed with great interest by the masses, emerging from various disciplines such as cinema, music, design, politics, sports, and are influential in the clothing styles of every period.

Throughout history, there are many people who became famous for various reasons. However, few of these celebrities have a unique style. The most important feature that distinguishes these celebrities, who can be as influential on fashion as a fashion designer, even though they are from different fields, from fashion followers, is the clothing styles that reflect their personality without fear. The icons, who use clothes that express their individuality, social identity and change the perspective of the future outside of their time, are like unique objects that describe the philosophy, aesthetic understanding and history of the age they live in. Marliene Dietrich, the pioneer of women wearing trousers, is a good example of these definitions and as the most influential style icon of the 1930s (Akyol, 2007, p. 8).

The common feature of icons, which mean 'symbol' in English, is not that they follow fashion, but that they can direct fashion. At the beginning of the 20th century, when consumption accelerated, a rapid development was seen in the fashion industry, just like the cinema, music and advertising industries, and the knock-on effect of these sectors on each other increased. Fashion icons formed in this way have 
Varola, E., (2021). Being a style icon in fashion world: Iris Apfel. Global Journal of Arts Education. 11(1), 89-101. https://doi.org/10.18844/gjae.v11i1.5727

influenced large masses. Some of the women considered as icons in the history of fashion are Josephine de Bonaparte, Queen Marie Antoinette, Greta Garbo, Elsa Schiaparelli, Catherine Deneuve, Vivienne Westwood, Grace Kelly, Coco Chanel, Audrey Hepburn and Twiggy (Guler, 2013, pp. 115-129). One of the examples of today's style icon women is the 99-year-old Iris Apfel.

\subsection{Style icon Iris Apfel}

\subsubsection{Life and career}

Iris Apfel (Barrel), the only child of her family, was born in 1921 in Astoria, Queens, New York. She studied art history at New York University and art history at the University of Wisconsin. As a young woman, Apfel worked for interior designer Elinor Johnson, writing articles for Women's Wear Daily and also assisted illustrator Robert Goodman. Iris Apfel, who married Carl Apfel on February 22, 1948, founded Old World Weavers, a textile company, and worked in this company until 1992 when they retired. Apfel, who served as a visiting professor at the University of Texas' Textile and Apparel Department in 2011, starred in a commercial for a French car brand in 2016 and became the brand face of an Australian brand. In 2018, he published the book 'Iris Apfel: Accidental Icon' (URL-2).

Describing himself as 'the world's oldest living teenager', Apfel's exhibition titled 'Rara Avis (Rare Bird): The Irreverent Iris Apfel' in 2005 focused on clothes and accessories and style. In New York, he met with the audience at the Metropolitan Museum of Art. Apfel was the oldest cover face of Vogue Italy and Dazed magazines at the age of 91 . He also signed a modelling contract with IMG in 2019 at the age of 97 (URL-3).

For Iris Apfel, who is a source of inspiration for many designers and brands, Jimmy Choo prepared a special collection called 'Iris Apfel' in 2013 (Figure 2) (URL-4). Apfel also has a colouring book for adults.

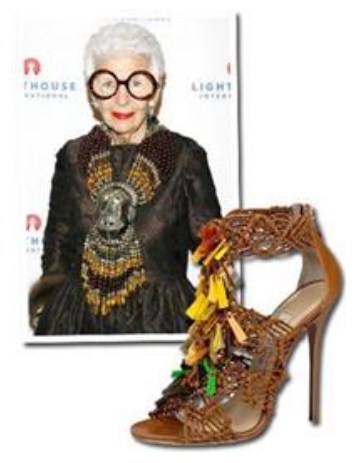

Figure 2. Jimmy Choo brand, Iris Apfel shoe sample (URL-5)

\subsubsection{Her perspective on fashion and views on her style}

Iris Apfel's point of view on fashion, being as an icon of style and by dressing well: 'I have always been like nobody. I always dressed the way I like. I always say, it's better to be happy than to dress well, so looking good is great, but if it becomes a chore and makes you nervous and uncomfortable, it's not worth it. Life is very grey and the world is not the kindest place, so I think fashion should always be fun' (Figure 3). Stating that she finds it fun to be a style icon in the fashion world today, she states that she does nothing different than 70 years ago (URL-6). 
Varola, E., (2021). Being a style icon in fashion world: Iris Apfel. Global Journal of Arts Education. 11(1), 89-101. https://doi.org/10.18844/gjae.v11i1.5727

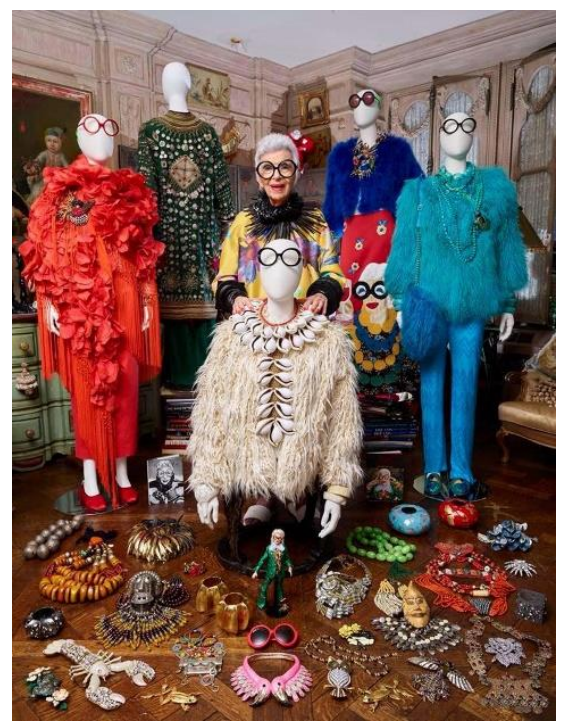

Figure 3. Examples of Apfel's clothing style, accessories and jewellery (URL-7)

The following are 11 quotes from Iris Apfel's thought-provoking, inspirational and sometimes entertaining quotes about fashion, style and life (URL-8):

1. 'When you don't dress like everyone else, you don't have to think like everyone else.'

2. 'If you make a mistake in what you put together (combine), the fashion police will not put you in jail.'

3. 'I don't see anything so wrong with the wrinkle. It's kind of like a badge of courage.'

4. 'I don't expect to be inspired. It comes to me somehow. Sometimes you step on a bug and get inspired.'

5. 'The two most important things for a woman in living a good life in New York are a driver and a furlined coat.'

6. 'Fashion is what you can buy, but style is what you have.'

7. 'If your hair is done properly and you wear good shoes, you can cope with anything.'

8. 'There is no map showing the way to style. Style is about self-expression and, above all, attitude.'

9. 'I don't dress to be looked after. I dress for myself.'

10. 'If you're not interested, you're not interesting.'

11. 'You have to try. You only have one trip, you shouldn't forget that.'

As can be understood from the theoretical framework summarised above, Iris Apfel, who has a very colourful, extraordinary and sophisticated style, is the subject of this study. In this direction, the aim of the research is to examine the clothing styles of Iris Apfel as a style icon, with both the style and all the visual elements that make up this style (clothes, accessories, jewellery, hair, make-up etc.).

\section{Method}

The method of this research is the case study, which is one of the qualitative research methods in line with the research problem the data obtained and the method used in analysing these data. The case study according to Yin (1984, p. 23) with the transfer of Yildirim and Simsek (2013, p. 313) states that: 'It 
Varola, E., (2021). Being a style icon in fashion world: Iris Apfel. Global Journal of Arts Education. 11(1), 89-101. https://doi.org/10.18844/gjae.v11i1.5727

is an empirical research method that works on a current phenomenon within its own real life framework, is used when the boundaries between the fact and its content are not clear and when there are more than one source of evidence or data'. In addition, this research is a holistic single-case pattern in terms of case study designs. In this design, there is only one unit of analysis such as an individual, an institution or a program (Yildirim \& Simsek, 2013, p. 326).

In line with the research problem and purpose, the style icon Iris Apfel and her clothing style were addressed with all aspects. In this direction, 10 visuals of the icon were randomly obtained online on the computer and it was analysed visually in line with the clothing style features of the icon.

\section{Findings and interpretation}

The findings obtained by examining the images taken and chosen randomly in the research are as follows:

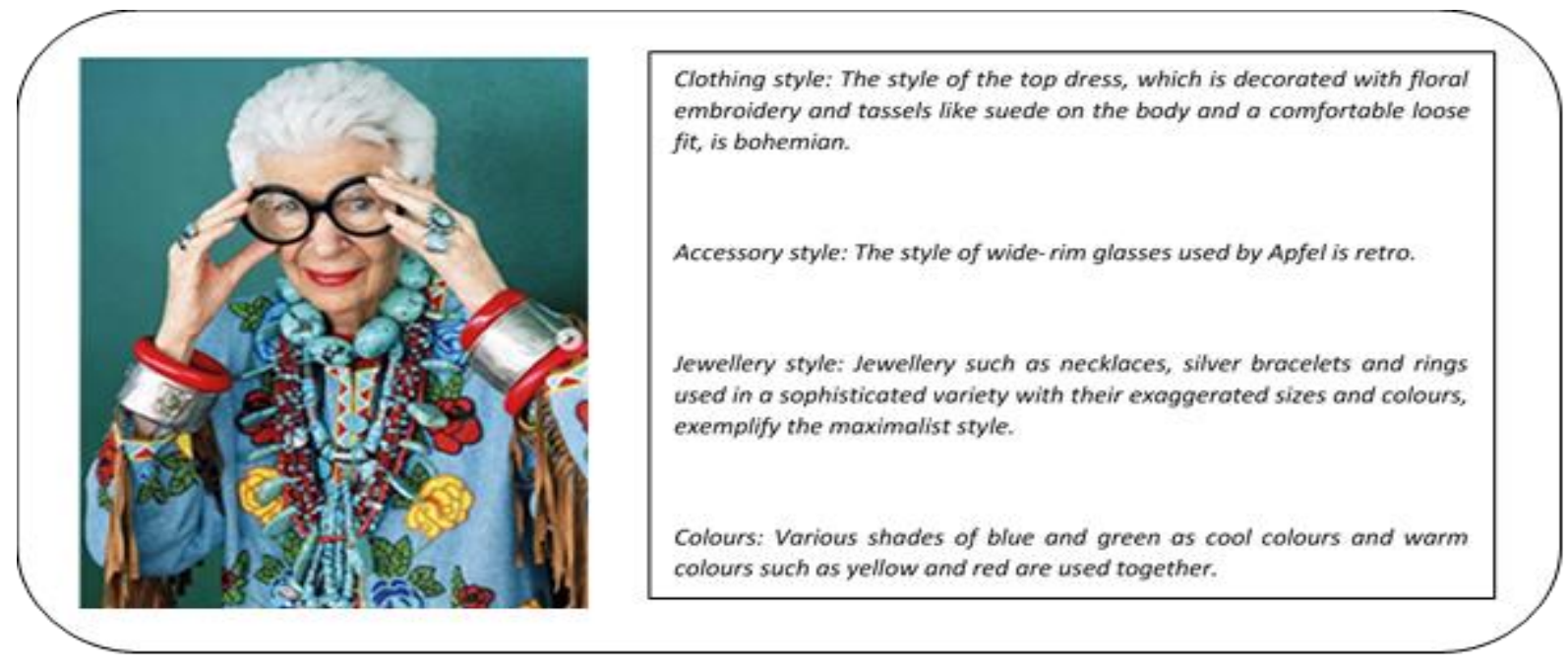

Figure 4. Iris Apfel'e ait stil ornegi 1 (URL-9)

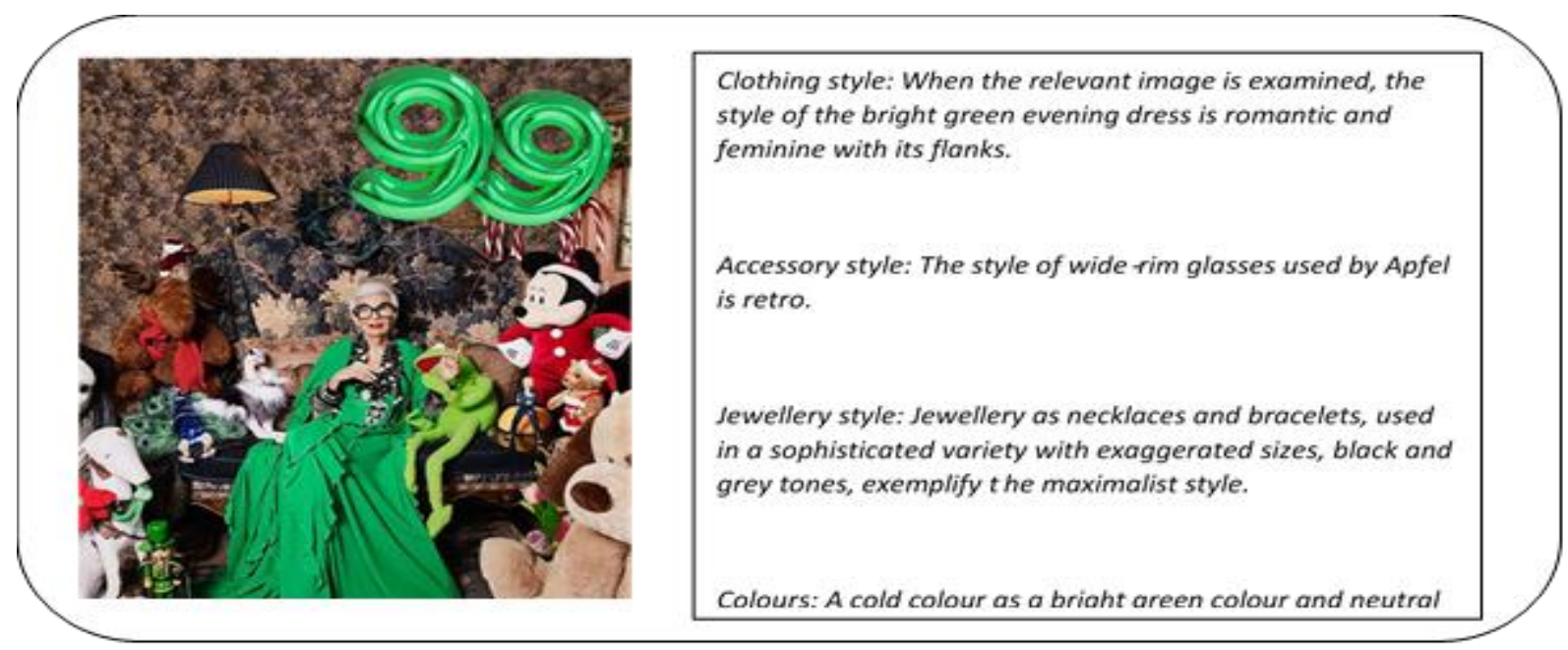

Figure 5. Iris Apfel'e ait stil ornegi 2 (URL-10) 
Varola, E., (2021). Being a style icon in fashion world: Iris Apfel. Global Journal of Arts Education. 11(1), 89-101. https://doi.org/10.18844/gjae.v11i1.5727
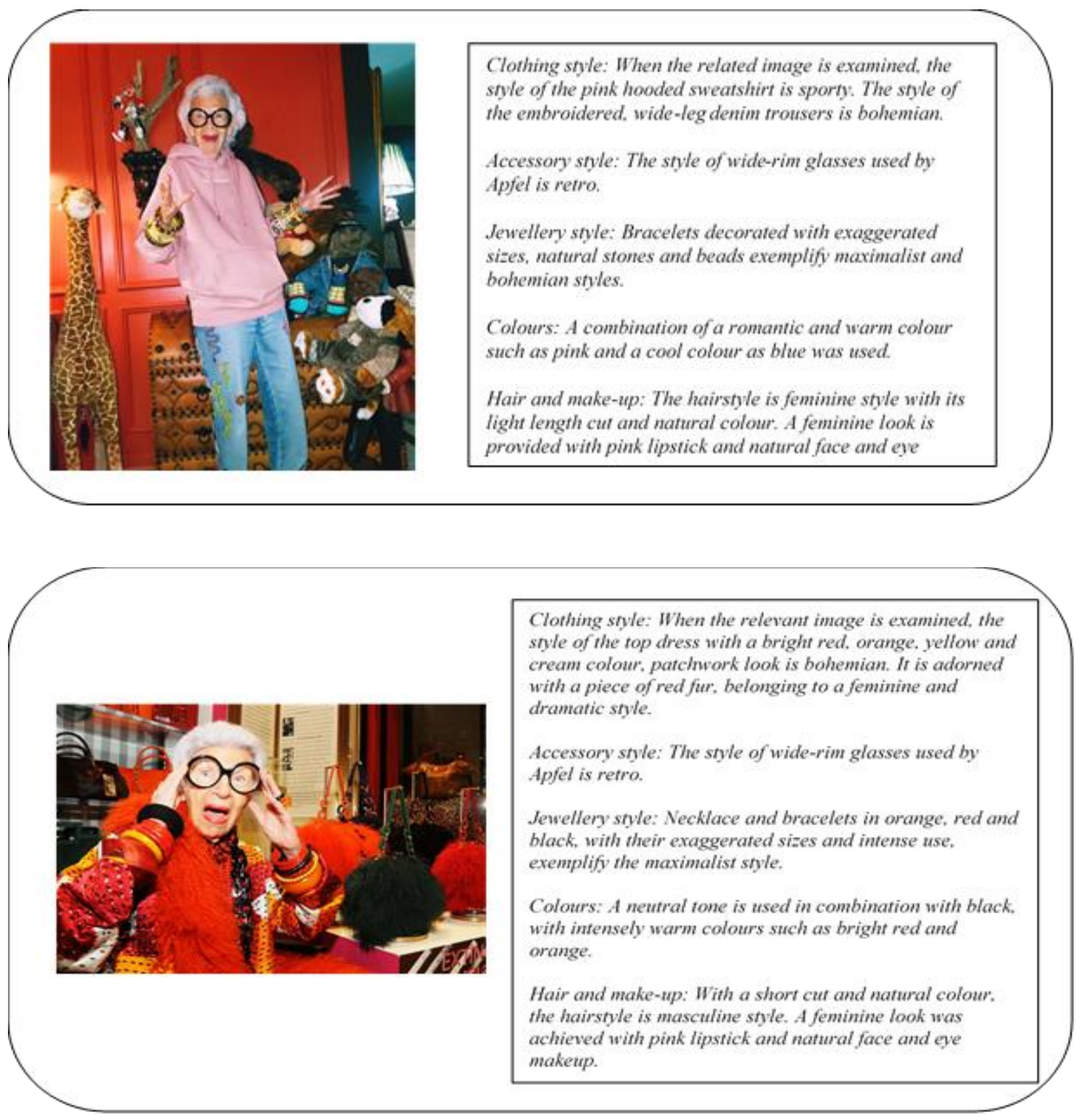
Varola, E., (2021). Being a style icon in fashion world: Iris Apfel. Global Journal of Arts Education. 11(1), 89-101. https://doi.org/10.18844/gjae.v11i1.5727

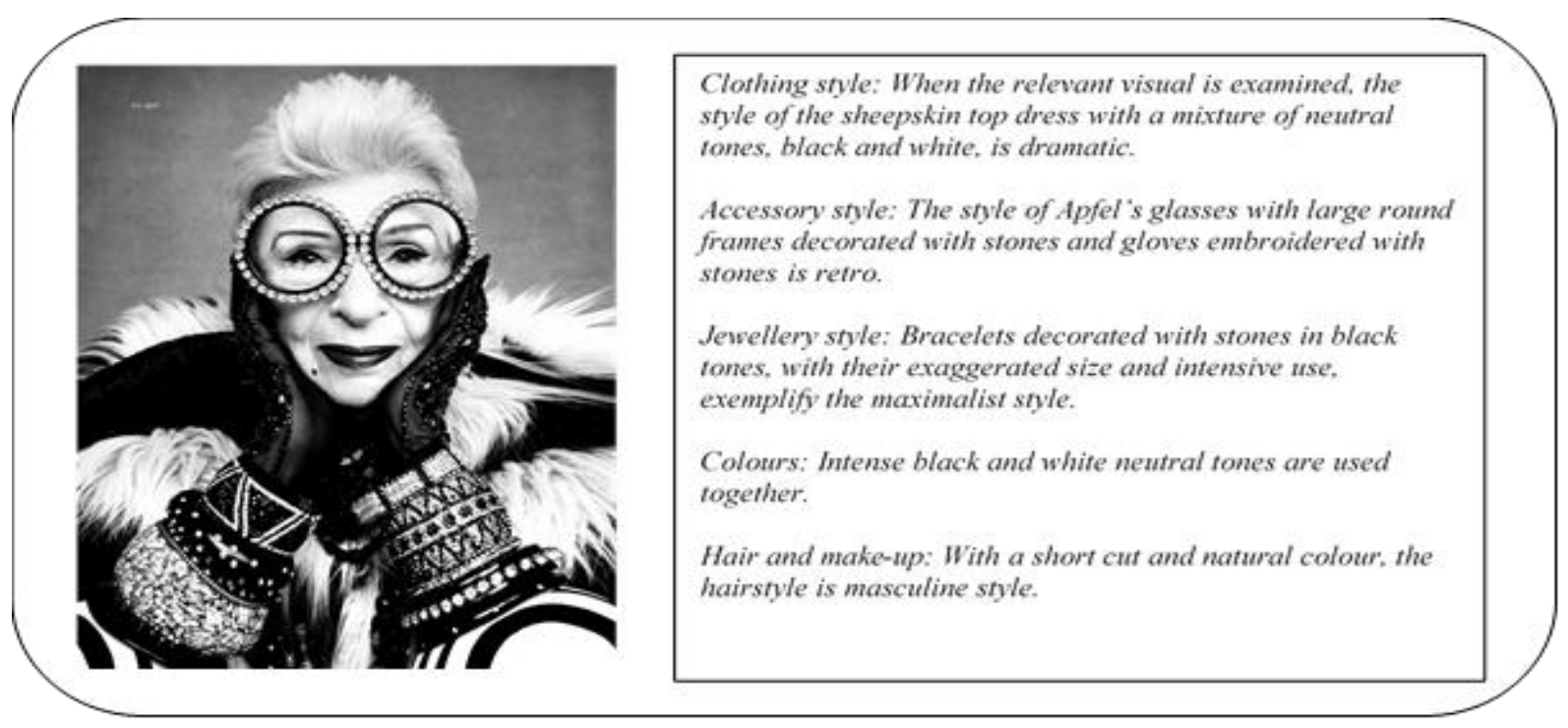

Figure 8. Style example of Iris Apfel 5 (URL-12)

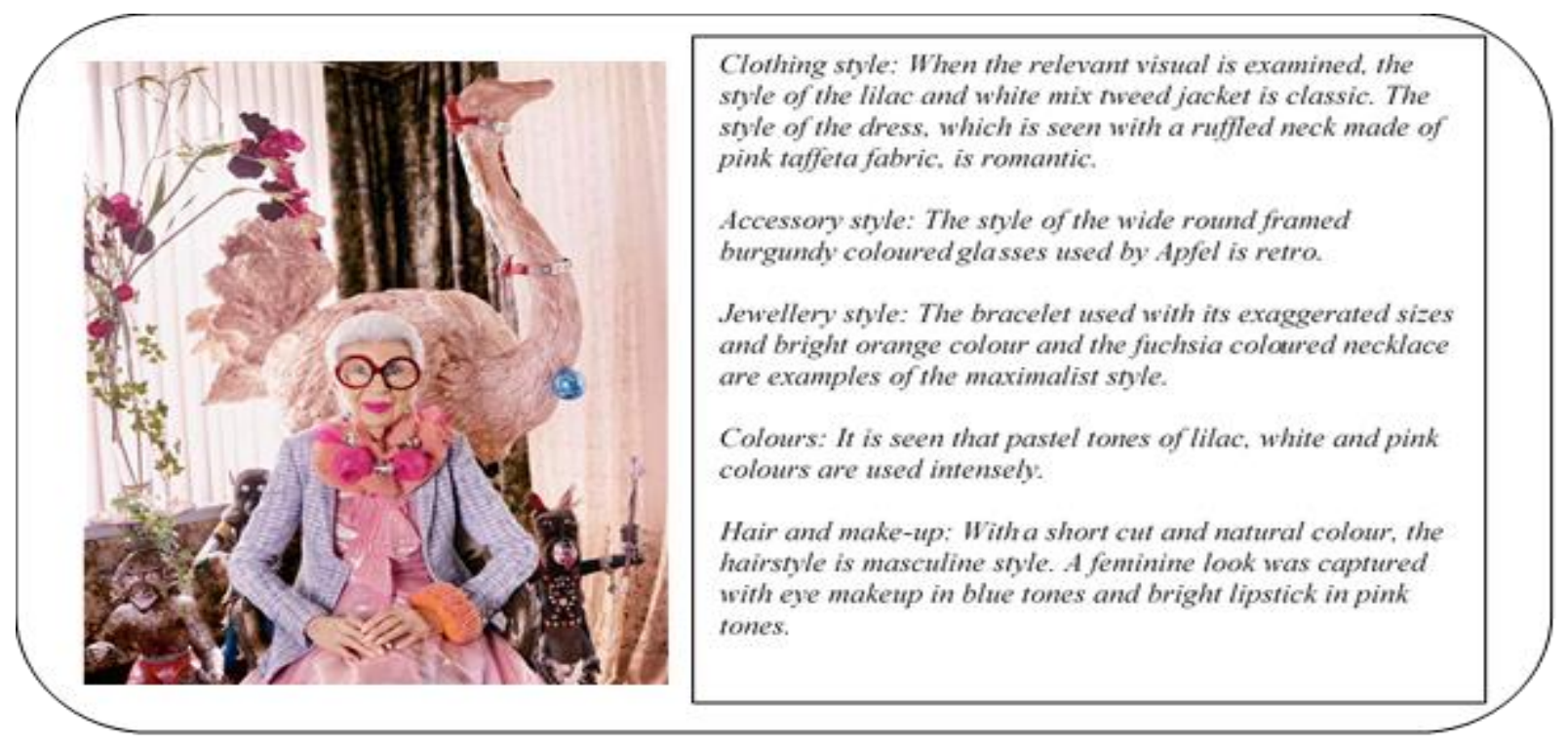

Figure 9. Style example of Iris Apfel 6 (URL-13) 
Varola, E., (2021). Being a style icon in fashion world: Iris Apfel. Global Journal of Arts Education. 11(1), 89-101. https://doi.org/10.18844/gjae.v11i1.5727

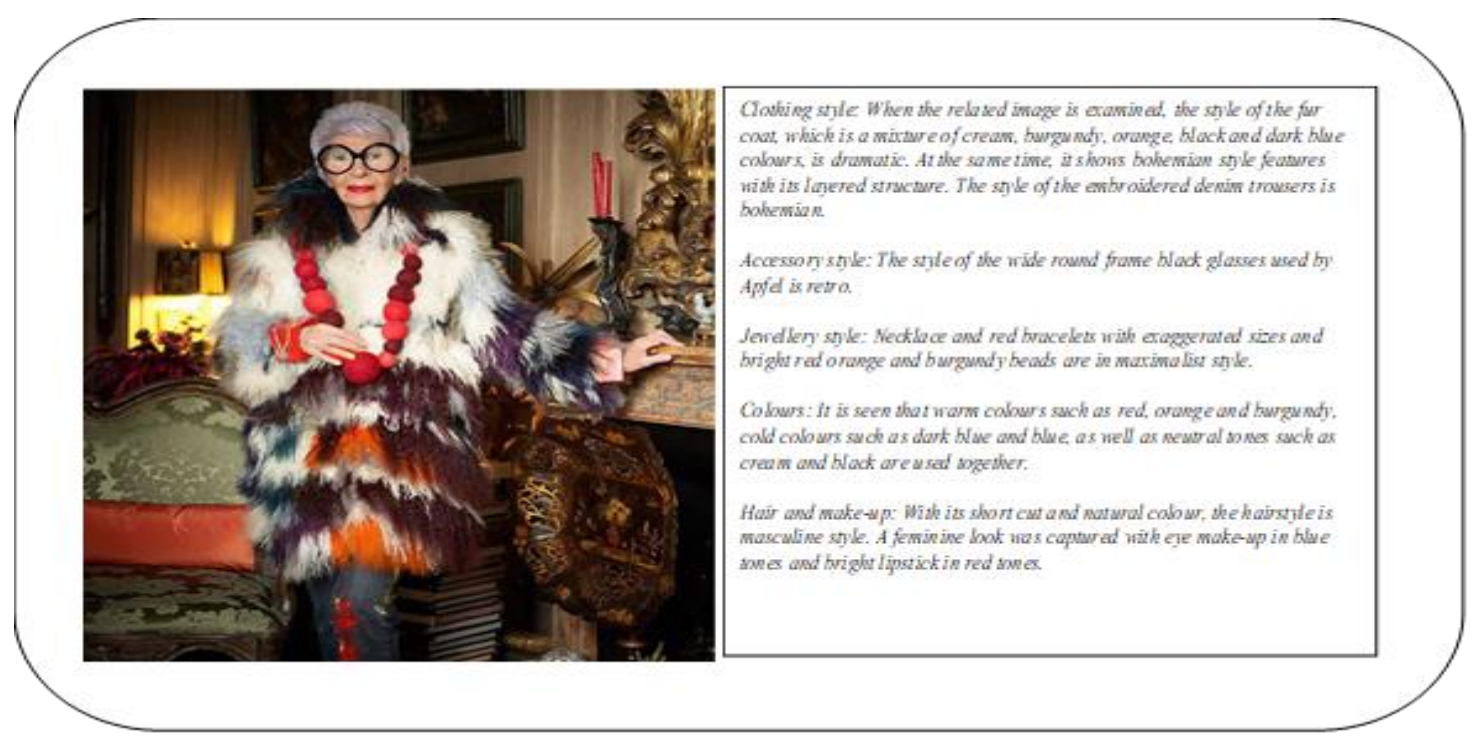

Figure 10. Style example of Iris Apfel 7 (URL-14)

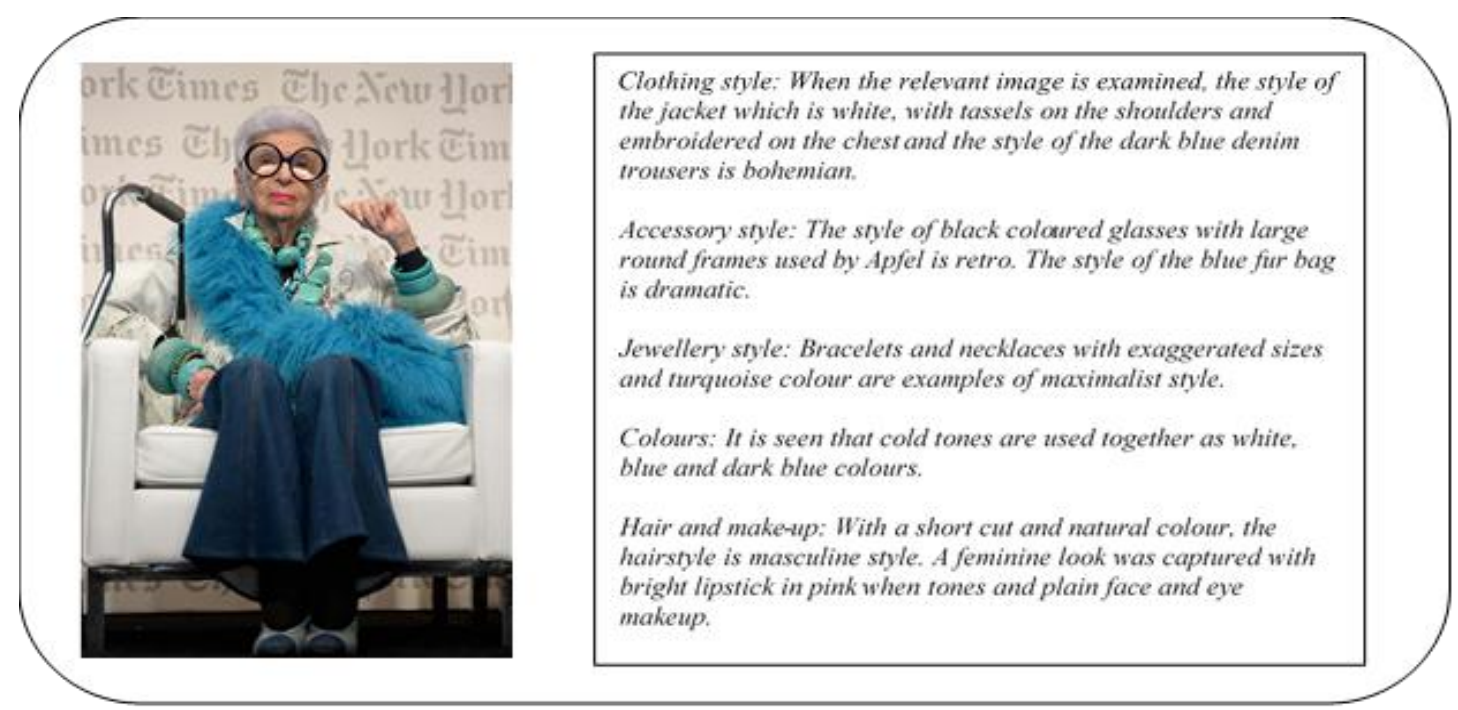

Figure 11. Style example of Iris Apfel 8 (URL-15)

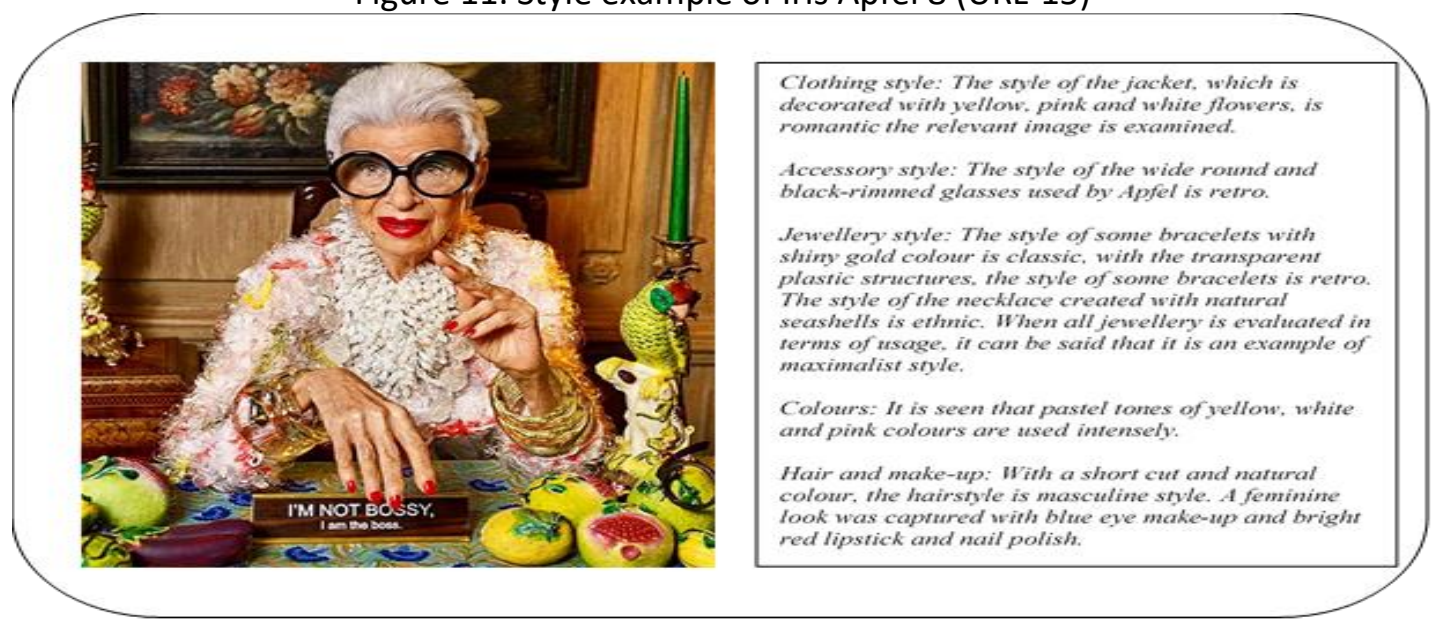

Figure 12. Iris Apfel'e ait stil ornegi 9 (URL-16) 
Varola, E., (2021). Being a style icon in fashion world: Iris Apfel. Global Journal of Arts Education. 11(1), 89-101. https://doi.org/10.18844/gjae.v11i1.5727

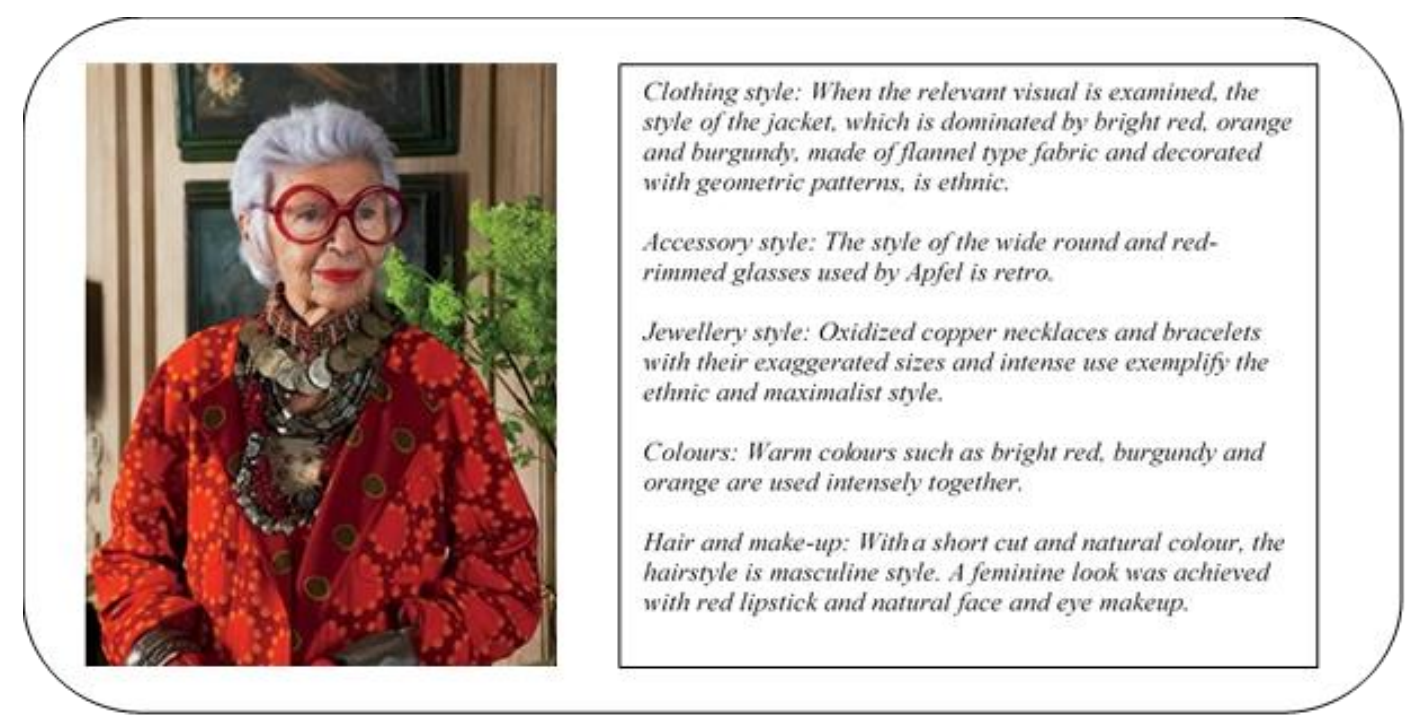

Figure 13. Style example of Iris Apfel 10 (URL-17)

\section{Conclusion}

The systematic way of combining clothes and complementary accessories in a correct and striking way by using design elements, such as style or personal style, colour, pattern and texture, are non-verbal communication tools in expressing personality, character and attitude towards life (Isler et al., 2018, p. 3) ). In order to have a personal style that is effective in creating the right, original and desired image, the person should know himself/herself well, know body features, clothing styles, colour theories, clothing types and usage places and design principles. Accordingly, the 99-year-old icon Iris Apfel, who has a unique personal style and can direct fashion with her style, is the subject of this study. Concerning the personal style of Iris Apfel, the results obtained are in line with the findings from the analysis of the images discussed in the research, which are as follows: Apfel has a very unique style with her knowledge and experience in the subjects of dressing styles, colour theories, usage areas and design principles of accessories and jewellery. When this style is handled in general terms, Apfel, who can combine many different styles of clothing, such as bohemian, sporty, romantic, dramatic or ethnic, has a style that can be described as more maximalist, sophisticated and sometimes chaotic.

- The jewellery preferred by her sets an example for the maximalist style, with their size and colour as well as their usage styles and densities.

- Complementing Apfel's personal style clothing and even an icon, retro glasses are the most striking accessory she uses.

- Apfel can combine saturated, bright, contrasting or pastel tones, warm or cold, with many different colours in clothing, accessories and jewellery with an aesthetic point of view.

- Apfel has a masculine approach with her hair style and a feminine approach with her make-up.

\section{References}

Akyol, Y. (2007). Examination of style icon phenomenon in terms of textile fashion (Master Thesis). Mimar Sinan Fine Arts University, Institute of Social Sciences, Textile and Fashion Design Department, Istanbul. 
Varola, E., (2021). Being a style icon in fashion world: Iris Apfel. Global Journal of Arts Education. 11(1), 89-101. https://doi.org/10.18844/gjae.v11i1.5727

Baudot, F. (2001). Century of Fashion (N. Akatli, Trans.). Istanbul, Turkey: Contemporary Publishing.

Cakir, O. (2002). Personal image and social life label in professional life. Istanbul, Turkey: Yapi Kredi Publications.

Davis, F. (1997). Fashion, culture and identity (O. Arikan, Trans.), Istanbul, Turkey: Yapi Kredi Publications.

Ermert, E. (2019). Encyclopedic dressing and fashion dictionary. Istanbul, Turkey: Hayalperest Publishing House.

Faux, S. (1999). Wardrobe solutions. London, UK: Marshall Publishing.

Girvy, V.D. (1999). Fashion and art, P culture art and Antique Magazine. Portakal Culture and Art Publishing House, 12.

Guler, S. (2013). Image and style coaching. Istanbul, Turkey: Alfa Publishing Distribution.

Hakko, C. (1983). Fashion phenomenon. Ankara, Turkey: Vakko Publications.

Isler, M., Bor Kocaman, A. \& Kilinc, N. (2018). Comparison of the styles fashion design students have and reflect on their designs (pp. 1-18). 3rd International Eurasian Sports, Education and Society Congress Full Text Book.

Lin, C. H. (2007). Evaluating fashion design information: the creation of assessment measures for the evaluation of fashion design using a MAL module to enhance fashion design information and analysis of fashion curriculum at a Taiwan University (PhD. Dissertation). Idaho State University, Graduate School, Department of Instructional Methods \& Technology, USA.

McKelvey, K. \& Munslow, J. (2003). Fashion design: process, innovation \& practice. Oxford, UK: Blackwell Publishing.

Olgaç, P. (2014). Fashion design-style and image. Ankara, Turkey: Sistem Ofset Publishing.

Sampson, E. (1995). Image factor (H. Ilgun, Trans.). Istanbul, Turkey: Route Broadcasting Promotion.

Tok Dereci, V. (2017). Understanding fashion trend predictions in the field of clothing design. Journal of Academic Perspective, 59, 73-89.

Varol, E. (2017). Style in choosing clothes. In F. Curaoglu (Ed.), In the book of clothes selection (pp. 4159). Eskisehir, Turkey: AOF Publications.

Yildirim, A. \& Simsek, H. (2013). Qualitative research methods in the social sciences (Extended 9th ed.). Ankara, Turkey: Seckin Publishing.

\section{Internet Resources Used}

URL-1: www.sozluk.gov.tr

URL-2: https://en.wikipedia.org/wiki/Iris_Apfel

URL-3: https://www.businessoffashion.com/community/people/iris-apfel

URL-4: https://www.elle.com.tr/moda/moda-haberleri/iris-apfel

URL-5: https://www.instyle.com.tr/jimmy-choodan-iris-apfele-ovgu-2005

URL-6: https://www.harpersbazaar.com/uk/fashion/fashion-news/a33390077/iris-apfel-life-is-very-greyso-fashion-should-always-be-fun/

URL-7: https://www.facebook.com/IrisApfelofficialphotos/a.4655023069491561555514457947930 
Varola, E., (2021). Being a style icon in fashion world: Iris Apfel. Global Journal of Arts Education. 11(1), 89-101. https://doi.org/10.18844/gjae.v11i1.5727

URL-8: https://www.harpersbazaar.com.au/fashion/11-inspiring-quotes-from-iris-apfel-7734

URL-9: https://www.instagram.comp/CFOEfg3hytS

URL-10: http://swww.instagram.comp/CEeYnjnhOUw

URL-11: https://www.instagram.comp/CAaVLyYAUcK

URL-12: https://www.facebook.com/IrisApfelofficialphotos/a.4564849811842221673149136184461

URL-13: https://www.facebook.com/IrisApfelofficialphotos/a.4655023069491561571019086397467

URL-14: https://www.facebook.com/IrisApfelofficialphotos/a.4655023069491561566426480190061

URL-15: https://www.harpersbazaar.com.au/fashion11-inspiring-quotes-from-iris-apfel-7734

URL-16: https://www.facebook.com/IrisApfelofficialphotos/a.4655023069491561538225413010168

URL-17: https://40plusstyle.com/style-icon-iris-apfel/ 